\title{
Statistical Optimization for Application of Nonionic Surfactants in Enzymatic Hydrolysis of Palm Fiber for Ethanol Production
}

\author{
Jatuporn Parnthong and Suratsawadee Kungsanant
}

\begin{abstract}
Palm fiber is a lignocellulosic material, which is available in large quantity from oil palm industry. Due to its cellulosic structure, it is considered as a highly potential alternative material for ethanol production. Thus, the palm fiber is utilized as a raw material in this study. The palm fiber is obtained from local industry and mechanically ground to reduce the size in the range of $0.417-1 \mathrm{~mm}$. Then, it is pretreated with $10 \%$ sodium hydroxide. Then, it is further utilized in the enzymatic hydrolysis. The commercial cellulase enzyme (Trichoderma reesei) is employed in this study. The nonionic surfactant (Tween80) is applied to enhance the conversion of cellulose to sugar. In the experiment, the effects of enzyme loading, surfactant concentration, and hydrolysis time on sugar yield are investigated at $50{ }^{\circ} \mathrm{C}$ and $\mathrm{pH}$. By employing the response surface methodology, optimum sugar yield was obtained at as high as $67.65 \%$ from palm fiber at $107 \mathrm{~h}$ hydrolysis time, 20 FPU/g substrate enzyme loading, and 7.39 $\mathrm{g} / \mathrm{L}$ surfactant concentration.
\end{abstract}

Index Terms-Palm fiber, ethanol, enzymatic hydrolysis, nonionic surfactant, response surface method.

\section{INTRODUCTION}

Currently, ethanol is considered as one of the most important liquid biofuels. Thus, there is growing interest in producing the ethanol from lignocellulosic materials such as wood chips, straw, corn cob, palm fiber, oil palm empty fruit bunch, etc. In this work, palm fibers are utilized as a lignocellulosic material for ethanol production due to their large availability from oil palm industry especially in the southern part of Thailand. Moreover, the physical characteristics of palm fiber are very suitable for ethanol production [1], [2].

In conversion of the palm fibers to ethanol, enzymatic hydrolysis is a significant step to obtain high content of fermentable sugars during the ethanologenic fermentation. In this step, enzyme is determined as a high performance catalyst. In addition, it reduces corrosion of equipment and is environmentally friendly [1], [3].

Moreover, many research works reported that the addition of nonionic surfactant in enzymatic hydrolysis could increase hydrolysis rate of enzyme [4]-[7]. This is because surfactants could adsorb on lignin, leading to avoiding unproductive binding of enzymes to lignin [3], [4], [7]. In addition, other mechanisms have been reported. For examples, the surfactants change the ultra-structure of the substrate, making

Manuscript received September 5, 2013; revised November 3, 2013.

The authors are with the Department of Chemical Engineering Prince of Songkla University, Hat Yai, Songkhla, 90112, Thailand (e-mail: suratsawadee.k@psu.ac.th). the cellulose more available to enzymatic attack; the surfactants increase enzyme stability, etc [4].

Therefore, this work aims to study the sugar production from the enzymatic hydrolysis of palm fiber enhanced by nonionic surfactants. The experiment is statistically designed to observe the optimum condition of three factors, which are hydrolysis time, enzyme loading, and surfactant concentration, using a response surface method (RSM).

\section{MATERIALS AND METHODS}

\section{A. Materials}

Palm fibers were obtained from a palm oil extraction plant (The Southern Palm (1978) Co., Ltd.). The palm fibers were dried under sunlight for 2 days. Then, they were cut with the blender and screened to obtain the size in the range of 0.44 $\mathrm{mm}-1 \mathrm{~mm}$ by standard sieve. The Trichoderma reesei (T. reesei, Sigma-Aldrich) with filter paper activity of 0.4598 FPU/mg solid was utilized as a cellulase enzyme. The nonionic surfactant (Tween 80) was purchased from Sigma-Aldrich.

\section{B. Pretreatment}

A quantity of $10 \mathrm{~g}$ of the palm fibers $(0.04 \mathrm{~mm}-1 \mathrm{~mm})$ was added to $100 \mathrm{~mL}$ of $10 \% \mathrm{w} / \mathrm{v} \mathrm{NaOH}$, and the mixture was boiled for $15 \mathrm{~min}$ and then washed with distilled water until the $\mathrm{pH}$ was neutral. After that, it was dried in the oven and stored at room temperature.

\section{Hydrolysis}

The pretreated palm fibers $(0.6 \mathrm{~g})$ were added to the bottles containing cellulase enzyme (T. reesei) with $10 \mathrm{FPU} / \mathrm{g}$ substrate and surfactant in $30 \mathrm{~mL}$ of citric buffer $(\mathrm{pH} 5)$. The bottles were incubated with a shaking rate of $160 \mathrm{rpm}$ at $50^{\circ} \mathrm{C}$.

TABLE I: CODES AND ACTUAL LEVELS OF THE INDEPENDENT VARIABLES FOR DESIGN OF ENZYME HYDROLYSIS EXPERIMENT USED IN THE CCD

\begin{tabular}{lcccccc}
\hline \hline \multirow{2}{*}{ Independent variables } & \multirow{2}{*}{$\begin{array}{c}\text { Coded } \\
\text { symbol }\end{array}$} & \multicolumn{5}{c}{ Code and Actual factor levels } \\
\cline { 3 - 7 } & $X_{1}$ & 24 & 43 & 72 & 101 & 120 \\
\hline $\begin{array}{l}\text { Hydrolysis time (h) } \\
\text { Enzyme loading } \\
\text { (FPU/g substrate) }\end{array}$ & $X_{2}$ & 5 & 8 & 13 & 17 & 20 \\
$\begin{array}{l}\text { Surfactant } \\
\text { concentration (g/L) }\end{array}$ & $X_{3}$ & 0 & 3 & 8 & 12 & 15 \\
\hline \hline
\end{tabular}

\section{Experimental Design}

The RSM was used to optimize the enzymatic hydrolysis based on a central composite design (CCD) to study the 
combined effect of three independent variables, which were hydrolysis time $\left(X_{1}, h\right)$, enzyme loading $\left(X_{2}\right.$, FPU/g substrate), and surfactant concentration $\left(X_{3}, \mathrm{~g} / \mathrm{L}\right)$. Each variable was varied at five levels $(-\alpha,-1,0,1,+\alpha)$ as shown in Table I. The sugar yields were calculated according to the following equation:

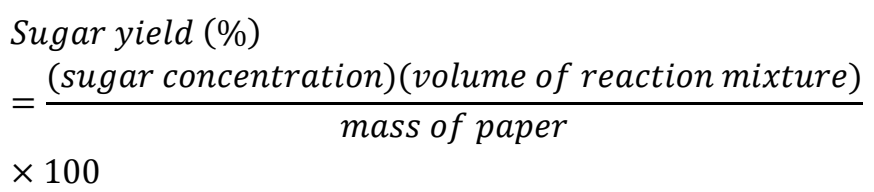

\section{E. Analytical Method}

The cellulose and lignin contents were determined by A.O.A.C. method [8]. The sugar concentrations were analyzed using the 3,5-dinitrosalicylic acid reagent (DNS) method and measured by UV-visible spectrophotometer (HP 8453).

\section{RESUlTS AND DISCUSSION}

\section{A. Sodium Hydroxide Pretreatment}

Table II shows that after pretreating the palm fibers with $10 \% \mathrm{w} / \mathrm{v} \mathrm{NaOH}$, the cellulose composition increased from $41 \%$ to $57.33 \%$, and lignin composition decreased from $11 \%$ to $9.67 \%$. As a result, palm fibers utilized in this work are pretreated with $10 \% \mathrm{w} / \mathrm{v} \mathrm{NaOH}$ and then used in enzymatic hydrolysis.

\section{B. RSM Analysis}

The experimental designs with the observed and predicted sugar yield values are presented in Table III.

TABLE II: THE COMPOSITION OF PALM FIBERS

\begin{tabular}{lll}
\hline \hline Pretreatment & Cellulose (\%) & Lignin (\%) \\
\hline No pretreatment & 41 & 11 \\
Sodium hydroxide & 57.33 & 9.76 \\
\hline \hline
\end{tabular}

TABLE III: CCD WITH THE OBSERVED AND PREDICTED VALUES OF THE EXPERIMENTAL RESPONSES

\begin{tabular}{crrrcc}
\hline \hline Run & $X_{1}$ & $X_{2}$ & $X_{3}$ & $\begin{array}{c}\text { Observed } \\
\text { Sugar yield } \\
(\%)\end{array}$ & $\begin{array}{c}\text { Predicted } \\
\text { Sugar yield } \\
(\%)\end{array}$ \\
\hline 1 & 0 & -2 & 0 & 24.54 & 28.60 \\
2 & 0 & 0 & -2 & 29.10 & 34.17 \\
3 & 1 & 1 & 1 & 56.83 & 65.04 \\
4 & 0 & 2 & 0 & 66.83 & 66.85 \\
5 & 2 & 0 & 0 & 67.19 & 66.21 \\
6 & 1 & -1 & 1 & 56.68 & 52.31 \\
7 & 0 & 0 & 0 & 46.89 & 47.73 \\
8 & -2 & 0 & 0 & 24.19 & 20.15 \\
9 & -1 & 1 & -1 & 50.27 & 46.90 \\
10 & -1 & -1 & -1 & 20.08 & 14.49 \\
11 & 0 & 0 & 2 & 49.12 & 44.57 \\
12 & 1 & 1 & -1 & 69.93 & 66.21 \\
13 & -1 & 1 & 1 & 50.94 & 55.03 \\
14 & -1 & -1 & 1 & 19.67 & 20.67 \\
15 & 1 & -1 & -1 & 41.28 & 46.13 \\
16 & 0 & 0 & 0 & 49.88 & 47.73 \\
17 & 0 & 0 & 0 & 53.54 & 47.43 \\
\hline \hline
\end{tabular}

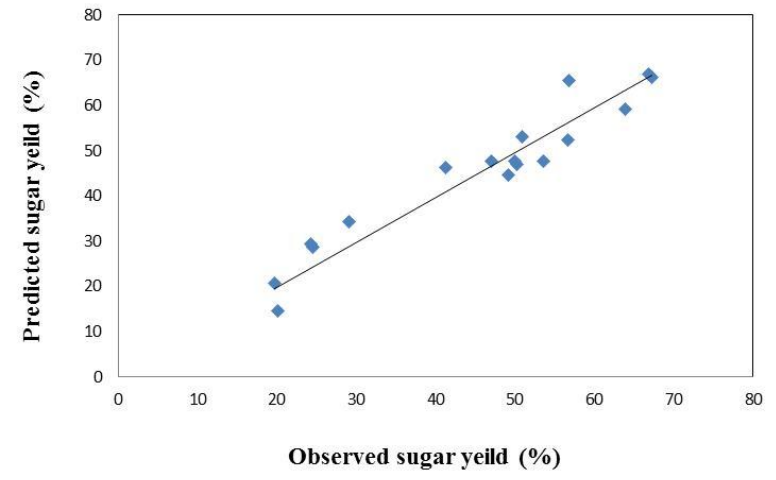

Fig. 1. Sugar yields calculated from the quadratic models versus the corresponding experimentally measured values.

The final response functions in term of coded factors to predict sugar yields eliminating the insignificant terms are given in the following equation:

$$
\begin{gathered}
Y=-59.61+0.860 X_{1}+5.285 X_{2}+ \\
2.922 X_{3}-0.149 X_{3}^{2}-0.0379 X_{1} X_{2}
\end{gathered}
$$

where $Y$ (sugar yield) is the predicted response as a function of hydrolysis time $\left(X_{1}\right)$, enzyme loading $\left(X_{2}\right)$ and surfactant concentration $\left(X_{3}\right)$.

The $R^{2}$ value from the model is 0.94 and $R^{2}$ adjusted value is 0.88 . Fig. 1 presents the comparison between the actual response values obtained from the experiments and the predicted response values based on the quadratic model equation of sugar yield. It also demonstrates that the predicted and observed results are consistent.

\section{Effect of Hydrolysis Time and Enzyme Loading}

The predicted response surface for sugar yields from palm fibers as functions of hydrolysis time and enzyme loading is presented in Fig. 2. The results show that sugar yield increased with increasing hydrolysis time and enzyme loading. In short time period, it should be noted that the increase in enzyme loading has a significant role on sugar yield [3].

\section{Effect of Hydrolysis Time and Surfactant Concentration}

The predicted response surface for sugar yields from palm fibers as functions of hydrolysis time and surfactant concentration is presented in Fig. 3. It can be seen that as the surfactant concentration is varied in range of $0-15 \mathrm{~g} / \mathrm{L}$, the highest sugar yield is observed at $7.39 \mathrm{~g} / \mathrm{L}$.

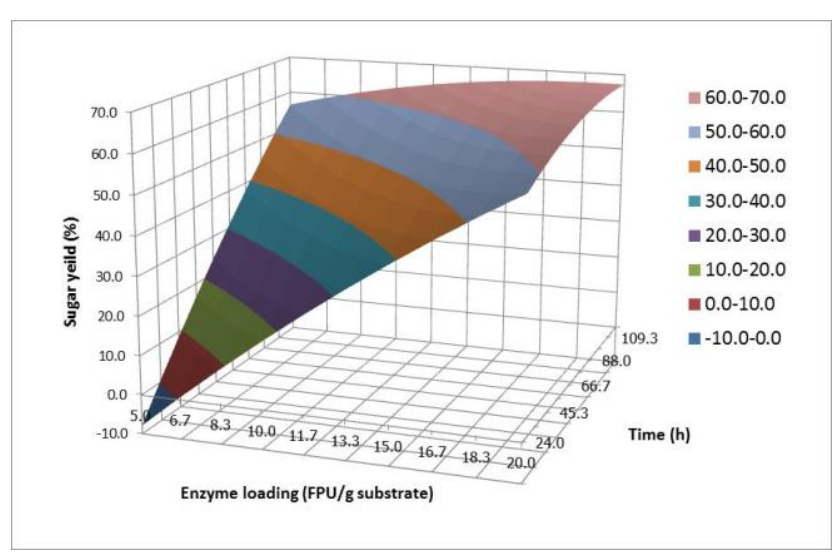

Fig. 2. Response surface plot showing the effect of hydrolysis time and enzyme loading on sugar release from palm fiber. 


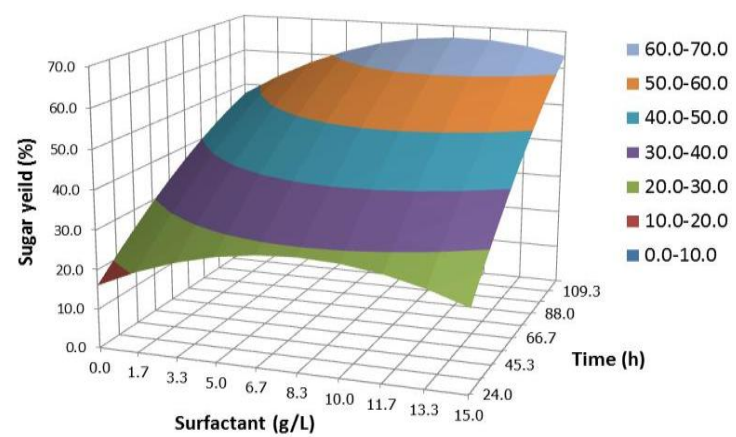

Fig. 3. Response surface plot showing the effect of hydrolysis time and surfactant concentration on sugar release from palm fiber.

\section{E. Effect of Surfactant Concentration and Enzyme Loading}

The response surface for sugar yields from palm fiber as functions of surfactant concentrations and enzyme loading is presented in Fig. 4. It can be seen that as the surfactant concentration increased from 0 to $15 \mathrm{~g} / \mathrm{L}$, the local maximum value at the center of the design is observed at $7.39 \mathrm{~g} / \mathrm{L}$ surfactant concentration. In addition, the higher enzyme loading, the greater sugar yields. The results also show that the addition of surfactant could increase rate of enzymatic hydrolysis especially in the region of low enzyme loading. The ability of nonionic surfactant to minimize nonproductive and irreversible binding of cellulose to lignin might be the reason for this benefit [4]. However, as the surfactant concentration is increased greater than $7.39 \mathrm{~g} / \mathrm{L}$ the sugar yield tends to decline. This might be due to the increase in the number of micelles in the solution. The greater micelle formation could enhance the partitioning of the enzyme into the surfactant micelles, leading to the reduction of free enzyme available for hydrolysis. In addition, the $\mathrm{pH}$ of the solution could be changed at high surfactant concentration [3]. Therefore, surfactant is suitable to enhance saccharification of cellulose to glucose with low enzyme loading.

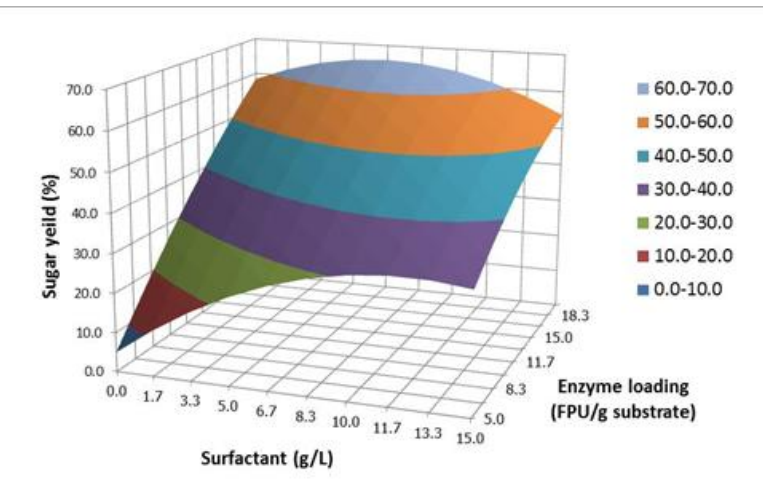

Fig. 4. Response surface plot showing the effect of surfactant concentration and enzyme loading on sugar release from palm fiber.

\section{F. Optimization}

The local optimization calculated from the statistical model shows that the sugar yield of $67.65 \%$ from palm fiber was achieved at $107 \mathrm{~h}$ hydrolysis time, $20 \mathrm{FPU} / \mathrm{g}$ substrate enzyme loading, and $7.39 \mathrm{~g} / \mathrm{L}$ surfactant concentration.

\section{CONCLUSIONS}

The RSM could be employed to optimize three factors, which are hydrolysis time, enzyme loading, and surfactant concentration, for the enzymatic hydrolysis of palm fiber. The addition of low concentration of nonionic surfactant could increase sugar yield at optimum concentration, revealing the ability of the nonionic surfactant to minimize nonproductive binding of enzyme to lignin. Thus, the nonionic surfactant could enhance conversion of cellulose to glucose especially with low enzyme loading. The role of surfactant on enzymatic hydrolysis and the effect of surfactants on ethanol fermentation should be further discussed.

\section{ACKNOWLEDGMENT}

We would like to acknowledge the materials and financial supported from The Southern Palm (1978) Co., Ltd., Department of Chemical Engineering, Bio-gas and research center in Department of Environmental Engineering, faculty of Engineering, and the graduate school of Prince of Songkla University.

\section{REFERENCES}

[1] P. Boonsawang, Y. Subkaree, and T. Srinorakutara, "Ethanol production from palm pressed fiber by prehydrolysis prior to simultaneous saccharification and fermentation (SSF)," Biomass and Bioenergy, vol. 40, pp. 127-132, 2012.

[2] F. Hamzah, A. Isris, and T. K. Shuan, "Preliminary study on enzymatic hydrolysis of treated oil palm (Elaeis) empty fruit bunches fibre (EFB) by using combination of cellulose and $\beta$ 1-4 glucosidase," Biomass and Bioenergy, vol. 35, pp. 1055-1059, 2011.

[3] K. H. Chu and X. Feng, "Enzymatic conversion of newpaper and office paper to fermentable sugars," Process Safety and Environmental Protection, vol. 91, pp. 123-130, 2013.

[4] T. Eriksson, J. Borjesson, and F. Tjerneid, "Mechanism of surfactant effect in enzymatic hydrolysis of lignocellulose," Enzyme and Microbial Technology, vol. 31, pp. 353-364, 2002.

[5] H. J. Kim, S. B. Kim, and C. J. Kim, "The effects of nonionic surfactants on the pretreatment and enzymatic hydrolysis of recycled newpaper," Biotechnology and Bioprocess Engineering, vol. 12, pp. 147-151, 2007.

[6] N. Hemmatinejad, F. Vahabzadeh, and S. S. Kordestani, "Effect of surfactant on enzymatic hydrolysis of cellulosic fabric," Iranian Polymer Journal, vol. 11, pp. 333-338, 2002.

[7] M. Alkasrawi, T. Eriksson, J. Borjesson, A. Wingren, M. Galbe, F. Tjerneld, and G. Zacchi, "The effect of Tween20 on simultaneous saccharification and fermentation of softwood to ethanol," Enzyme and Microbial Technology, vol. 33, pp. 71-78, 2003.

[8] Y. Subkaree, "Optimal condition for ethanol production from palm pressed fiber using simultaneous saccharification and fermentation (ssf)," M. D., Department of Biotechnology, Faculty of Argo-Industry, Prince of Songkla University, Hadyai, Thailand, 2007.

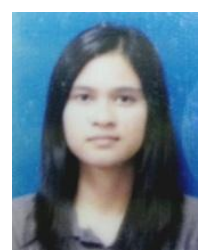

Jatuporn Parnthong is a graduate student who has received her master's degree, she was with the Department of Chemical Engineering, Prince of Songkla University Scholarship Awards during Enrolment: Prince of Songkla University for Graduate Studies Grant.

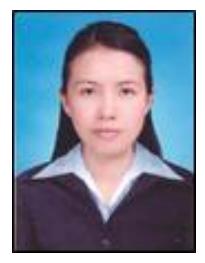

Suratsawadee Kungsanant received her $\mathrm{Ph} . \mathrm{D}$ in petrochemical technology, she was with the Department of Chemical Engineering, Prince of Songkla University, now she is a lecturer. 